\title{
Nauruan classification
}

\author{
Kevin Hughes*
}

\begin{abstract}
Nauruan is a Micronesian language that has been classified outside of the Nuclear Micronesian group. This classification suggests that Nauruan, unlike all other Micronesian languages, did not descend from Proto-Micronesian. Though this view has been adopted in the literature, it should be considered tenuous. It is based on little Nauruan data and is informed by work that is presented as highly tentative. This paper presents a reassessment of Nauruan classification, drawing on data from original fieldwork. Research shows not only that Nauruan is a Micronesian language, but that there is no compelling evidence for classifying Nauruan apart from the Nuclear group. Of particular importance is the claim that Nauruan fails to reflect the merger of Proto-Oceanic $*_{\mathrm{d}}$ and $*_{\mathrm{dr}}$ as Proto-Micronesian $*_{\mathrm{c}}$ (Jackson 1986). Comparative evidence suggests that Nauruan does reflect this merger: POc $* \mathrm{~d}, * \mathrm{dr}>\mathrm{PMc} * \mathrm{c}>$ r. It follows that Jackson's classification for Nauruan is unmotivated, as is the Nuclear/non-Nuclear distinction within the family. Having established that Nauruan need not be classified apart from the Nuclear group, Nauruan's precise classification within the Micronesian family is considered. A question of primary importance is whether Nauruan reflects the merger of ProtoMicronesian *s and $* S$. The possibility that Nauruan did not participate in this merger is considered, in which case Nauruan should be classified outside of the Central Micronesian group, like Kosraean. The possibility that Nauruan did participate in this merger is also considered, in which case Nauruan should be classified somewhere within Central Micronesian. Further, some innovations are described which are potentially shared between Nauruan and certain Central Micronesian languages. The possibility that these are shared innovations is considered, as are the implications this would have for Nauruan classification.
\end{abstract}

Keywords. Micronesian languages; Oceanic languages; Austronesian languages; historical linguistics; Nauru; Nauruan

1. Introduction. The prevailing view on Nauruan classification is that it should be classified apart from the Nuclear Micronesian group, as illustrated in Figure 1. ${ }^{1}$ This classification suggests that Nauruan is the only Micronesian language that did not descend from ProtoMicronesian. The idea that Nauruan should be classified apart from the other Micronesian languages has appeared in the literature for some time, though Jackson (1986) presents the only argument for this classification that is supported by any Nauruan data. Earlier researchers had little Nauruan data to go on, which made it difficult to present well-supported arguments for Nauruan classification. Jackson himself describes the data available to him as "quite meager" (1986:211). Despite the tentative nature of the claim, the idea that Nauruan is non-Nuclear has persisted in the literature (e.g., Lynch et al. 2011:117). §2 presents a review of the literature

\footnotetext{
*Author: Kevin Hughes, City University of New York (khughes2@gradcenter.cuny.edu).

${ }^{1}$ Individual Pohnpeic and Chuukic languages are not shown here. Pohnpeic languages include Pohnpeian, Mokilese, and Pingelapese. Chuukic languages include Mortlockese, Chuukese (Trukese), Puluwatese, Saipan Carolinian, Saipan Carolinian (Tanapag), Satawalese, Woleaian, Pulo-Annan, Sonsorolese, and Ulithian.
} 


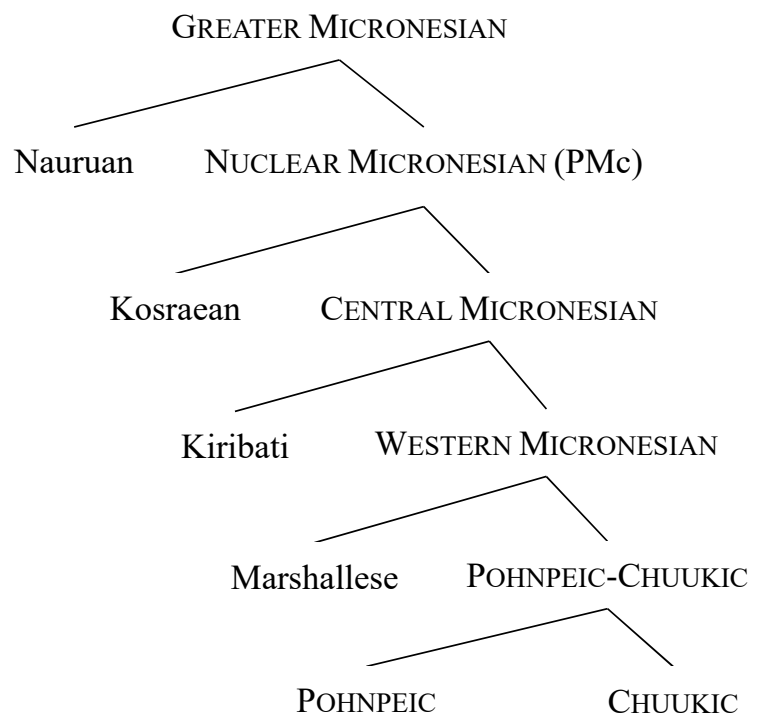

Figure 1. The Greater Micronesian Family (Jackson 1986)

on Nauruan classification, including a summary of Jackson's (1986) arguments for excluding Nauruan from the Nuclear Micronesian group.

This paper reevaluates Nauruan classification based on new data from original fieldwork and recent comparative work (Hughes 2020). Hughes presents a description of Nauruan synchronic phonology, including an account of the Nauruan phoneme inventory, reproduced in Table 1. Hughes compiles nearly 300 lexical comparisons, establishes regular sound correspondences between Proto-Oceanic (POc), Proto-Micronesian (PMc), Nauruan, and the other Micronesian languages, and identifies a range of morphological paradigms and phonological processes that have clear parallels across the Micronesian family and in Nauruan. The lexical comparisons can be found in the appendix provided by Hughes (2020:292-373). The sound correspondences are shown in Tables 2 and 3. These tables are presented here in abbreviated form, excluding correspondences for Pohnpeic and Chuukic languages, and with some minor corrections. $^{2}$ These and the original tables in Hughes (2020:176-177) are adapted from Bender et al. (2003), with Nauruan correspondences added. Other evidence discussed by Hughes in support of Nauruan's classification as Micronesian includes historic final vowel lenition, and the presence of recovered (or thematic) vowels stem-finally; diachronic regressive vowel assimilation; low vowel raising; diachronic low vowel dissimilation; interrelated processes of reduplication, vowel syncope and gemination; the transfer of vowel features to consonants;

\footnotetext{
${ }^{2}$ Corrections since Hughes (2020) include showing the underlying palatalization of Nauruan $/ \mathrm{b}^{\mathrm{j}} /$ and secondary articulations for $/ \mathrm{p}^{\mathrm{j}} /$ and $/ \mathrm{p}^{\mathrm{V}} /$. The Nauruan phonemes $/ \mathrm{p}^{\mathrm{j}} /, / \mathrm{p}^{\mathrm{V}} /, / \mathrm{k} /, / \mathrm{k}^{\mathrm{w}} /, / \mathrm{m}^{\mathrm{j}} /$ and $/ \mathrm{m}^{\mathrm{y}} /$ do not appear in Table 2 because they continue geminates that resulted from processes of reduplication and vowel syncope, rather than being direct continuations of PMc phonemes. The same is true of Nauruan /t/ where it continues pre-Nauruan *d: or $* \mathrm{n}$ : rather than being a direct continuation of $\mathrm{PMc} * \mathrm{t}$. Additionally, PMc *Z is reconstructed only for two etyma, PMc *kiaZo 'outrigger boom' and PMc *laZe 'a kind of coral', neither of which have identified Nauruan cognates. This is why "?" appears in place of a Nauruan correspondence for PMc *Z. Note also that Proto-Oceanic phonemes included by Bender et al. (2003) in Table 3 have been altered to maintain consistent representation of these sounds following Ross (1988).
} 


\begin{tabular}{|c|c|c|c|c|}
\hline \multicolumn{5}{|c|}{$\underline{\text { Consonants }}$} \\
\hline & Bilabial & Alveolar & Palatal & Velar \\
\hline Stop & $\begin{array}{ll}\mathrm{p}^{\mathrm{j}} & \mathrm{b}^{\mathrm{j}} \\
\mathrm{p}^{\mathrm{\gamma}} & \mathrm{b}^{\mathrm{y}}\end{array}$ & $\begin{array}{cc}\mathrm{t} & \mathrm{d} \\
\mathrm{t} \int & \mathrm{d}\end{array}$ & & $\underset{\mathrm{k}^{\mathrm{w}}}{\mathrm{k}} \mathrm{g}$ \\
\hline Nasal & $\begin{array}{cc}m^{j} \quad m^{j} \\
m^{\gamma} \quad m^{y}\end{array}$ & $\mathrm{n}$ & & $\eta$ \\
\hline Glide & (w) & & j j & $\mathrm{w}$ \\
\hline Rhotic & & $r \quad \check{r}$ & & \\
\hline
\end{tabular}

\begin{tabular}{ccccc} 
& & \multicolumn{1}{c}{ Vowels } & & \\
& Front & & Back & \\
High & i & $\dot{i}$ & u \\
Mid & e & & o \\
Low & $æ$ & a & \\
\hline
\end{tabular}

Table 1. The Nauruan Phoneme Inventory (Hughes 2020)

cognate morphological paradigms including pronominals, directionals, possessive classifiers, numerals, noun classifiers, and interrogatives; demonstratives that are continuations of combined PMc morphemes; and reflexes of PMc *te 'one', including the Nauruan nominal prefix /e-/ (Hughes 2020:247-280). The evidence strongly suggests that Nauruan is a Micronesian language, though one that has undergone a significant degree of internal sound change. A complete account of Nauruan internal sound change as it is currently understood is presented in Hughes (2020: Chapter 4, 173-175, 178-180). These internal sound changes include, among others, the development of voiceless stops from geminates following vowel syncope, e.g., *bVb $>* b b>* b$ : $>$ p; $* \mathrm{~g}>\mathrm{w}$ adjacent to rounded back vowels (PMc *k $>* \mathrm{~g}$ ); loss of ${ }^{*} \mathrm{w}$ word-initially; changes of ${ }^{*} \mathrm{~m}^{\mathrm{w}}$ to $/ \mathrm{y} /{ }^{*}^{\textrm{w}}{ }^{\mathrm{w}}$ to $/ \mathrm{m}^{\mathrm{y}} /$, and ${ }^{*} \mathrm{y}^{\mathrm{w}}$ to $/ \mathrm{g} /$; fortition of geminate $*_{\mathrm{w}}$ : to $/ \mathrm{k}^{\mathrm{w}} /$; changes of $*_{\mathrm{t}}$ and $* 1$ to $/ \mathrm{j} /$ adjacent to $* \mathrm{i}$ or $*$; prothetic $*_{\mathrm{w}}$ before stem-initial $* \mathrm{a}$ or $* \mathrm{i} ; \mathrm{PMc} * \mathrm{~S}>\mathrm{g}$ where $* \mathrm{~S}$ was continued adjacent to pre-Nauruan $*$; and a range of conditioned vowel changes. This high degree of internal sound change may have contributed to earlier perceptions of Nauruan as an outlier in the Micronesian family, though there appears to be no compelling evidence for excluding Nauruan from the Nuclear group. Of particular importance is Jackson's (1986) claim that Nauruan fails to reflect the merger of PMc *d and * $\mathrm{dr}$ as PMc *c, a merger which Nauruan does appear to reflect: POc *d, *dr $>$ PMc $* c>\check{r}^{3}{ }^{3}$ This undermines Jackson's primary argument for excluding Nauruan from the Nuclear group and by extension eliminates the need for the Nuclear/non-Nuclear distinction in the family. However, the question of Nauruan's precise classification within the family remains.

\footnotetext{
${ }^{3}$ In his article, Jackson represents POc $* \mathrm{~d}$ as $* \mathrm{nt}$ and POc $* \mathrm{dr}$ as *nd. These representations have been changed here to reflect revisions of the POc phoneme inventory by Ross (1988). Following Nathan (1973), Jackson represents the Nauruan fortis trill as "barred r", $f$. This sound is represented here as $/ \check{r} /$, following Hughes (2020).
} 


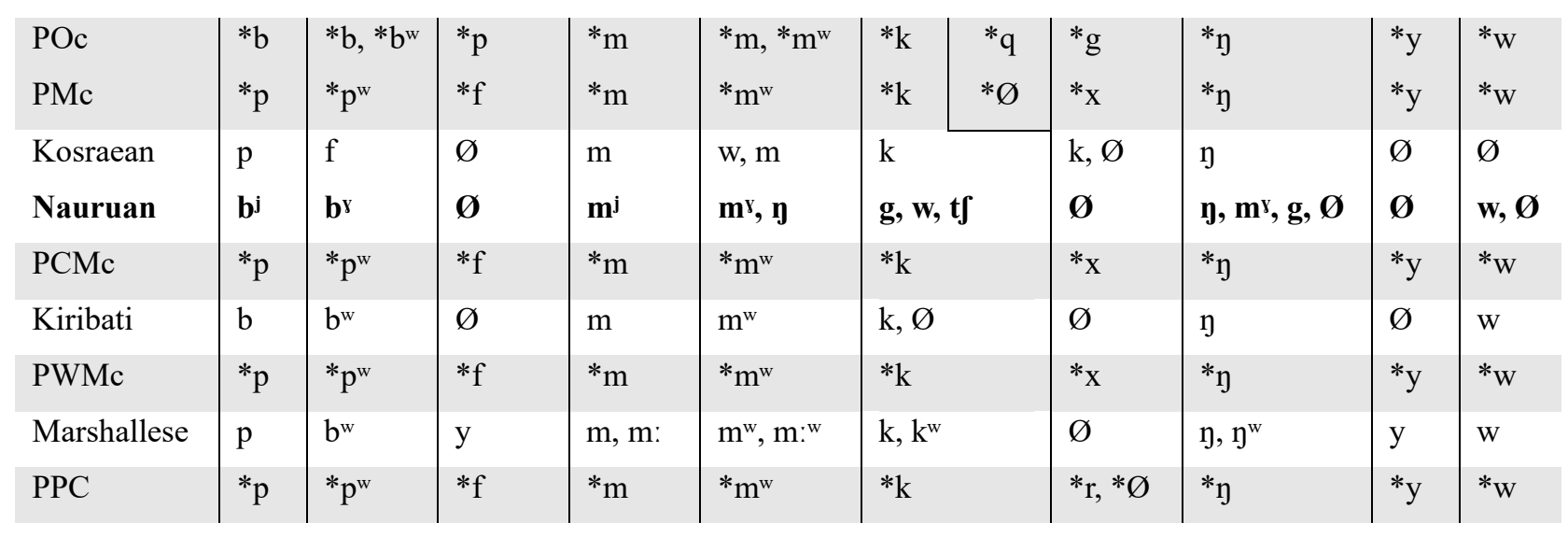

Table 2. Micronesian Consonant Correspondences: Labials, Velars and Glides

\begin{tabular}{|c|c|c|c|c|c|c|c|c|c|c|}
\hline $\begin{array}{l}\text { POc } \\
\text { PMc }\end{array}$ & $\begin{array}{l}*_{\mathrm{t}} \\
*_{\mathrm{t}}\end{array}$ & $* \mathrm{~T}$ & $\begin{array}{l}*_{\mathrm{s}},{ }^{*} \mathrm{j} \\
*_{\mathrm{s}}\end{array}$ & $\begin{array}{l}*^{*} \mathrm{c} \\
*_{\mathrm{S}}\end{array}$ & $\begin{array}{l}* \mathrm{c} \\
* \mathrm{Z}\end{array}$ & $\begin{array}{l}* \mathrm{~d},{ }^{*} \mathrm{dr} \\
{ }^{*} \mathrm{c}\end{array}$ & $\begin{array}{l}{ }^{*} \mathrm{r},{ }^{*} \mathrm{R} \\
{ }^{*} \mathrm{r}\end{array}$ & $\begin{array}{l}* 1 \\
* 1\end{array}$ & $\begin{array}{l}*_{n} \\
*_{n}\end{array}$ & $\begin{array}{l}*_{\tilde{n}} \\
*_{\tilde{n}}\end{array}$ \\
\hline $\begin{array}{l}\text { Kosraean } \\
\text { Nauruan }\end{array}$ & $\begin{array}{l}t, s \\
\mathbf{t}, \mathbf{j}\end{array}$ & $\begin{array}{l}\mathrm{s} \\
\mathbf{t}\end{array}$ & $\begin{array}{l}\mathrm{t}, \mathrm{s} \\
\mathbf{d}\end{array}$ & $\begin{array}{l}\varnothing \\
\text { d, } g\end{array}$ & $\begin{array}{l}\text { s } \\
?\end{array}$ & $\begin{array}{l}\mathrm{sr} \\
\check{\mathbf{r}}\end{array}$ & $\begin{array}{l}1 \\
\mathbf{r}\end{array}$ & $\begin{array}{l}1 \\
\mathbf{n}, \mathbf{j}, \mathbf{r}\end{array}$ & $\begin{array}{l}\mathrm{n} \\
\mathbf{n}, \mathbf{y}\end{array}$ & $\begin{array}{l}\tilde{n} \\
n, j\end{array}$ \\
\hline PCMc & $*_{\mathrm{t}}$ & $*^{\mathrm{T}}$ & $*_{\mathrm{s}}$ & $*_{\mathrm{s}}$ & $*_{\mathrm{z}}$ & $*_{\mathrm{c}}$ & $*_{\mathrm{r}}$ & $* 1$ & $* n$ & $*_{\tilde{n}}$ \\
\hline Kiribati & $\mathrm{t}, \varnothing$ & $\mathrm{t}$ & $r$ & $\mathrm{r}$ & $\mathrm{r}$ & $\mathrm{r}$ & $\varnothing$ & $\mathrm{n}$ & $\mathrm{n}$ & $\mathrm{n}$ \\
\hline PWMc & $*_{\mathrm{t}}$ & $* \mathrm{~T}$ & $*_{\mathrm{s}}$ & $*_{\mathrm{s}}$ & $* \varnothing$ & $*_{\mathrm{c}}$ & $* \mathrm{r}$ & $* 1$ & $* n$ & $* \tilde{n}$ \\
\hline Marshallese & $\mathrm{j}$ & $\mathrm{j}$ & $\mathrm{t}$ & $\mathrm{t}$ & $\varnothing$ & $\mathrm{d}\left[\mathrm{r}^{\mathrm{j}}\right]$ & $\mathrm{r}, \mathrm{r}^{\mathrm{w}}$ & $1,1,,^{\mathrm{w}}$ & $\mathrm{n}, \mathrm{n}, \mathrm{n}^{\mathrm{w}}$ & $\mathrm{n}$ \\
\hline PPC & $*_{\mathrm{t}}$ & $*^{\mathrm{T}}$ & $* \mathrm{~d}$ & $* d$ & $* \varnothing$ & $*_{\mathrm{c}}$ & $*_{\mathrm{r}}$ & $* 1$ & $*_{n}$ & $*_{\tilde{n}}$ \\
\hline
\end{tabular}

Table 3. Micronesian Consonant Correspondences: Coronals 
Given lack of evidence for excluding Nauruan from the Nuclear group, §3 considers different possible classifications for Nauruan within the Micronesian family. The main factor considered is whether or not Nauruan merged PMc *s and $* S$ as a single phoneme. This merger defines the Central Micronesian group, which includes all Micronesian languages other than Kosraean. If Nauruan fails to reflect this merger, then it must be excluded from the Central Micronesian group like Kosraean. If Nauruan does reflect this merger, then Nauruan must be classified somewhere within Central Micronesian. Data and analysis in Hughes (2020) suggests that Nauruan may have failed to undergo the merger of PMc *s and $* S$, but does not rule out the possibility that the merger occurred. Both possibilities are discussed, and the evidence that would confirm or refute the merger of PMc *s and *S in Nauruan is described. Additionally, some innovations that are potentially shared between Nauruan and certain Central Micronesian languages are discussed, as are the potential implications for Nauruan classification.

2. Nauruan classification in the literature. Dyen's (1965) lexicostatistical classification of Austronesian languages might be considered the first mention of Nauruan as a Micronesian outlier in the literature. Dyen places Nauruan on an independent branch of his Austronesian linkage, though he reports that Nauruan shares $16.1 \%$ of cognates with the "Carolinian Subfamily" which includes Micronesian (specifically Chuukic) languages (Bender et al. 2003). The relatively low percentage of Nauruan cognates in Dyen's study may be due to lack of data, though it seems likely that some cognates were simply not identified. As noted in $\S 1$, Nauruan has undergone a significant degree of internal sound change, and this makes some Nauruan cognates relatively opaque. Following Dyen (1965), Bender (1971) very briefly discusses Nauruan within his section on "questionably Nuclear languages". Following this, Nathan (1973) published the article Nauruan in the Austronesian Language Family, which is a highly tentative account of synchronic and diachronic Nauruan phonology. This work would go on to inform subsequent work on Nauruan phonology and sound change despite its tentative status. Nathan's article is the culmination of work that took place at the University of Hawaii in the early 1970s with a single visiting Nauruan consultant. Nathan ultimately concludes that Nauruan is likely to be a Micronesian language, but that a definitive classification awaits detailed comparison with Proto-Micronesian and individual Micronesian languages, research of the kind recently presented by Hughes (2020). Later, Marck (1975:28-31) classifies Nauruan apart from the Nuclear Micronesian group "as an immediate relative on the basis of phonological and morphophonemic comparisons." Drawing on data from Nathan (1973), Marck (1975:13) very briefly discusses evidence for Nauruan classification. ${ }^{4}$ However, most of what Marck discusses has been superseded by more recent work (Ross 1988, Bender et al. 2003). Marck does entertain the possibility that Nauruan is a Nuclear Micronesian language (1975:13, 24), even though his tree models of the Micronesian family exclude Nauruan from the Nuclear group. Marck states that if Nauruan is Nuclear, then it may be the most divergent member of this group (1975:13). Jackson (1986) provides the most thorough evidence-based argument for Nauruan classification up to the point of its publication, though it must be noted that he considers the Nauruan data available to him to be inadequate (1986:211). Jackson's classification has ultimately persisted in the literature despite its tentative status (e.g., Lynch et al. 2011:117). The following subsections summarize the arguments that Jackson makes, both for Nauruan's status as a Micronesian language and for its hypothesized exclusion from the Nuclear Micronesian group.

\footnotetext{
${ }^{4}$ Though Marck does not explicitly cite any Nauruan words, nor does he reproduce any of Nathan's data.
} 
2.1. JACKSON (1986): EVIDENCE THAT NAURUAN IS A MiCRONESIAN LANGUAGE. The crux of Jackson's argument regarding Nauruan classification is that it belongs outside of the Nuclear Micronesian group, but he also presents evidence that Nauruan is indeed a Micronesian language. Jackson (1986:204) identifies a set of 11 phonological innovations that define the Micronesian group, which Nauruan reflects in each case (Hughes 2020:234-240), and cites 12 specific pieces of evidence in support of classifying Nauruan as Micronesian (1986:212-213). Hughes (2020:240-247) examines each of these 12 pieces of evidence and finds that they remain well supported under new data and analysis. Jackson's evidence is presented below with a summary of comments from Hughes (2020) regarding each of his 12 points. ${ }^{5}$

1. "Like the Micronesian languages, Nauruan has developed labiovelar reflexes of both POc $* b$ and $* \mathrm{~m}$ before round vowels." This is clearly the case. POc *b is continued in Nauruan as $/ \mathrm{b}^{\mathrm{Y}} /$ or $/ \mathrm{p}^{\mathrm{y}} /$ where it preceded round vowels, and likewise, POc $* \mathrm{~m}$ is continued in Nauruan as $/ \mathrm{m}^{\mathrm{y} /}$ where it proceeded round vowels.

2. "PMc and Nauruan agree in showing retention or loss of POc * $\mathrm{R}$ in nine of the ten comparisons that have been identified (the exception is noted above)." ${ }^{\prime 6}$ In all cases identified so far, Nauruan agrees with the other Micronesian languages in the loss or retention of POc $* \mathrm{R}$.

3. "Nauruan has cognates of PMc *-ua 'counting classifier for general objects', *-manu 'counting classifier for animate and human objects' and *-cau 'counting classifier for thin flat objects' in the same meaning and function." Nauruan continues PMc *-ua in every numeral used in serial counting, with the possible exception of 'ten', e.g., PMc *rua-ua > a-ro 'two', PMc *lima-ua > e-jim ${ }^{\mathrm{j}}$ o 'five' (Hughes 2020:271). ${ }^{7}$ PMc *-manu is continued in some Nau-

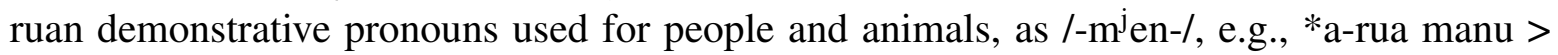
arum $^{j}$ en 'two people' (Hughes 2020:264, 273). The Nauruan noun classifier for flat objects is /-řræ-/, though proposed sound changes in Hughes (2020) suggest this continues a form of the shape *-caa rather than *-cau. Compare PMc *ca- 'state of being' which is continued in several Micronesian languages with meanings related to flatness, and note further that there is

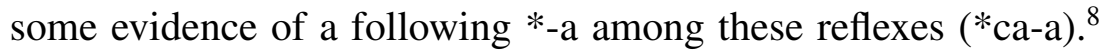

4. 'Nauruan $a$ - 'general possessive classifier' is cognate with PMc *a- in the same meaning and function." The morpheme that Jackson references here is /æ-/, which is a possessive classifier that appears to be used within predicate verb phrases in Nauruan, e.g., /eæd æ-i ediræ/, forgive POSS.CL-1SG NPFX-sin, 'forgive my sin/transgression'. This form likely continues PMc *aa- 'alienable object' (with possessive suffix), rather than PMc *a- as suggested by Jackson. ${ }^{9}$ The form /æ-/ suggests the following sound change: $*$ aa- $>$ *ea- $>$ *eæ- $>\mathfrak{x}-$. How-

\footnotetext{
${ }^{5}$ Some POc and PMc forms have been altered from Jackson's original article to follow the revised POc phoneme inventory proposed by Ross (1988).

${ }^{6}$ Jackson's exception is POc *qaRus(a), which he states is continued as Nauruan aar 'current'. Jackson may refer to Nauruan /æřæ-/ 'current, rip tide', though this word does not appear to continue the cited POc form.

${ }^{7}$ Nauruan numerals continue a prefix *a-, as /a-/ or /e-/. It is unclear if this prefix was present in PMc or if it developed at a later stage.

${ }^{8}$ Bender et al. (2003) reconstruct *ca- for Proto-Central Micronesian, though Hughes (2020) proposes this be reconstructed for Proto-Micronesian.

$9 *$ aa- 'alienable object' is reconstructed for Proto-Central Micronesian by Bender et al. (2003), but Hughes (2020) proposes that it also be reconstructed for Proto-Micronesian.
} 
ever, Nauruan does appear to have a reflex of PMc *a- in the possessive classifier /wa-/, e.g., /wa-m odo/, POSS.CL-2sG car, 'your car'. The initial/w/ in this morpheme is a result of glide prothesis, which occurs regularly in pre-Nauruan words that began with $*_{\mathrm{a}}$ or $*_{\mathrm{i}}$.

5. 'Nauruan nim 'drink, to drink' and nima- 'possessive classifier for drinkable objects' are cognate with PMc *nima and *nima- in the same meaning and functions, and are apparently unattested elsewhere [outside of the Micronesian family]." Bender et al. (2003) reconstruct PMc *nima- 'drinkable object', though they list no cognates for this reconstruction. Bender et al. cite Jackson's set of possessive classifiers for comparison (1986:208) and instruct readers to compare $\mathrm{PMc} * \mathrm{inu}$, *(i)nu-mi, *(i)nu-ma 'drink', which is continued in many Micronesian languages. The Nauruan possessive classifier for drinkable objects, /nim-/ (comparing Jackson's nima-), appears to be from PMc *nima- 'drinkable object', though the general verb for drink appears to have its source instead in PMc *(i)nu-mi given forms such as Nauruan /nimi-da/ 'drink up'.

6. 'Nauruan -oo 'demonstrative root: away from speaker and hearer' is almost certainly cognate with PMc *oe in the same meaning and function, but is also apparently not attested elsewhere [outside of the Micronesian family]." The suffix that Jackson cites appears to be Nauruan /-o/ rather than /-oo/. The Nauruan distal suffix is not a long vowel, nor does there appear to be contrastive vowel length in Nauruan generally. Nauruan appears to continue each of the PMc demonstrative suffixes suggested by Jackson (1986:208): *e 'near speaker', *na 'near addressee', *oe 'away from speaker and addressee'. However, it appears that Jackson mistakenly includes the construct suffix *-n- in his reconstruction of *na 'near addressee'. The relevant Nauruan suffixes include /-e/ 'here (proximal)', /-a/ 'there (medial)', /-o/ 'far away (distal)'. Further, the equivalent reconstructions from Bender et al. (2003) are somewhat different from Jackson's in both form and meaning. Compare PMc *ee 'here, this near speaker' and PMc *oo 'that (out of sight or in the past)'. Bender et al. do not reconstruct a medial demonstrative suffix of the shape *a, though compare PMc *-a 'him, her, it (object pronoun)' and PMc *aa- 'alienable object' (with possessive suffix), which may be cognates.

7. 'Nauruan $j i$ 'where' is very probably cognate with PMc *ia(a) 'where (to)?', other cognates of which are very rare in Oceanic." Jackson appears to reference Nauruan /i/ 'where' though there does not seem to be an initial consonant in this word. This word likely continues PMc *i- 'at (locative)' (Bender et al. 2003). Compare the following Nauruan words which derive from /i/ combined with genitive (sometimes called the "construct") suffix /-n/ and one of the three demonstrative suffixes denoting distance, /-e/, /-a/, /-o/: /ine/ 'here', /ina/ 'there', /ino/ 'way over there, a location out of sight'.

8. "Nauruan $e_{\Lambda} k \Lambda y$ 'sharp' appears to be cognate with PMc *kayi 'sharp', which represents an innovation from PEOc *kani." Jackson appears to cite the Nauruan word /eakay/ 'sharp', which is proposed to derive from PMc *kakayi 'sharp' with a prefix /ea-/ of unknown origin (Hughes 2020). ${ }^{10}$ Nauruan must continue the reduplicated form rather than PMc *kayi because Nauruan /k/ exclusively continues pre-Nauruan geminate *g. Where there is no subsequent gemination in pre-Nauruan, PMc $* \mathrm{k}$ is continued as Nauruan /g/ or is lost word-initially before *a.

9. "Nauruan $e-r \Lambda$ 'bone' is almost certainly cognate with PMc *cui, reflecting an earlier

\footnotetext{
$10 *$ kakani 'sharp' is reconstructed only for Proto-Central Microneisan by Bender et al. (2003), though Hughes (2020) proposes it be reconstructed for Proto-Micronesian.
} 
*duRi which is otherwise only attested in the Admiralties and some non-Oceanic Austronesian languages." Nauruan continues PMc *cuyi (Bender et al. 2003) as Nauruan /e-ř̀/ 'bone', though Jackson appears to misinterpret the final vowel in this word as $\Lambda$. This word reflects regular sound changes in Nauruan, including PMc $*^{*}>\check{\mathrm{r}}, \mathrm{PMc} * \mathrm{y}>\emptyset$, and PMc $* \mathrm{i}>\dot{\mathrm{i}}$ where $*_{\mathrm{i}}$ immediately followed $*_{\mathrm{w}}$ or $* \mathrm{u}$.

10. "Nauruan bwiribwir 'white' is cognate with the otherwise apparently innovative PMc

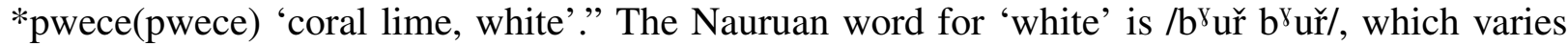
in pronunciation between [ $b^{\gamma}$ iř̀b ${ }^{\gamma}$ iř $]$ and [buřəbuř], though Jackson appears to interpret the underlying vowels as /i/. This word would seem to continue PMc ${ }^{*} \mathrm{p}^{\mathrm{w}} \mathrm{ecep}^{\mathrm{w}}$ ece 'white, powdered lime', as reconstructed by Bender et al. (2003), though the Nauruan vowel correspondence is irregular. The precise sound changes that account for the Nauruan vowel in this word remain unclear, but Jackson's overall point that Nauruan continues the PMc word for 'white' appears to be correct.

11. "Nauruan $m w i$ 'tooth' may reflect the type *jii 'tooth' reconstructed in Jackson (1984: 388) only for PCMc [Proto-Central Micronesian] because of the absence of a cognate form in Kosraean." Jackson's etymology for the Nauruan word for 'tooth' closely parallels the etymology proposed by Hughes (2020): POc *jipo > PMc * jio $>{ }^{*} \mathrm{y}^{\mathrm{w}} \mathrm{i}>$ Nauruan $/ \mathrm{m}^{\mathrm{y}} \mathrm{i}$-/ 'tooth'.

12. "Nauruan bwoodi- 'nose' is cognate with PMc *pwauzu in the same meaning." Bender et al. (2003) reconstruct PMc * $\mathrm{p}^{\mathrm{w}} \mathrm{auSu}$ 'nose', though Hughes (2020) suggests a slightly different reconstruction: PMc ${ }^{*} \mathrm{p}^{\mathrm{w}}$ au-uSi $>{ }^{*} \mathrm{~b}^{\mathrm{\gamma}} \mathrm{euDi}>{ }^{*} \mathrm{~b}^{\mathrm{y}}$ ouDi $>$ Nauruan $/ \mathrm{b}^{\mathrm{\gamma}}$ od $3^{\mathrm{i}-/}$ 'nose'. The reconstruction of an initial vowel in the proposed PMc morpheme ${ }^{*}$-uSi accounts for the failure of PMc *S to correspond to Nauruan /g/, as is observed adjacent to pre-Nauruan *o in a range of Nauruan words and allows for established regular sound changes. Reconstructing the final vowel as $*_{\mathrm{i}}$ accounts for several Micronesian cognates that end in $i$, including Nauruan $/ \mathrm{b}^{\mathrm{\gamma}}$ odzi-/. Compare Kiribati $b^{w}$ airi, Marshallese $b^{w}$ awat(iy), Mokilese $p^{w}$ oodi-, and Woleaian booti. Compare also POc *isu 'nose' which may have undergone metathesis to result in PMc *-uSi.

\subsection{JACKSON (1986): ARGUMENTS FOR EXCLUDING NAURUAN FROM THE NUCLEAR GROUP. As}

shown in $\$ 2.1$, Jackson's arguments for classifying Nauruan as a Micronesian language remain wellsupported under new data and analysis (Hughes 2020). A significant amount of additional evidence that Nauruan is a Micronesian language is presented by Hughes, as discussed in $\S 1$. However, Jackson's arguments that Nauruan should be excluded from the Nuclear Micronesian group are not well-supported (1986:212). The evidence that Jackson presents in support of this view is summarized and critiqued below.

Jackson's primary claim supporting the exclusion of Nauruan from the Nuclear Micronesian group is that it fails to reflect the merger of POc $* \mathrm{~d}$ and $* \mathrm{dr}$ as PMc $* \mathrm{c}$. Jackson argues that Nauruan continues each of these proto-phonemes independently: POc $* d>t, P O c * d r>r$. This proposal depends upon a single comparison, for the first person possessive inclusive suffix /-tæ/. Jackson considers that Nauruan /kætæ/ '1pl. inclusive accusative pronoun' and /-tæ/ '1pl. inclusive possessive suffix' continue POc *d as /t/, comparing POc *kida $>$ PMc *kica 'we, us (incl.)'. ${ }^{11}$ Because POc * $d r$ is continued as Nauruan $*$ r in the words $/$ ram $^{\gamma} \mathrm{a}-/$ 'forehead' (PMc *camª), /řæ-/ 'blood' (PMc *caa), and /řen/ 'juice, fresh water' (PMc *canu-), Jackson suggests that POc $* \mathrm{~d}$ and $* \mathrm{dr}$ did not merge in Nauruan, and therefore Nauruan must

\footnotetext{
${ }^{11}$ Jackson represents Nauruan $/ \mathrm{kætæ} /$ as kotá. The first vowel in this word appears to have been misinterpreted.
} 
be excluded from the Nuclear Micronesian group. However, Jackson is unaware of the doublet PMc *-ta '1pl. (incl.)' which has since been reconstructed by Bender et al. (2003; in PMc *kita) to account for reflexes of PMc *t in Marshallese kéj 'we, us (incl.)' and Kosraean kst, kite--(l) 'we, us (incl.)'. Nauruan clearly continues PMc *t in its first person plural inclusive pronominal morphemes, as Kosraean and Marshallese do: Nauruan /æ-tæ/, /kæ-tæ/ 'we, us (incl.); /-tæ/ '1pl. (incl.)'; /-tær/ '1dl. (incl.)' (PMc *rua 'two'); /-tej/ '1tr. (incl.)' (PMc *telu 'three'; PMc *t becomes Nauruan / $\mathrm{j} /$ adjacent to $* \mathrm{e}) .{ }^{12}$ Because of the reconstruction of the PMc doublet containing *t, Jackson's comparison does not provide good evidence for classifying Nauruan outside of the Nuclear Micronesian group. In all relevant comparisons discovered so far, Nauruan reflects the merger of POc $* d$ and $* \mathrm{dr}$ as PMc $* \mathrm{c}$, which is consistently continued as Nauruan /r̂. The Nauruan first person inclusive forms simply continue PMc *t as /t/.

In addition to his primary argument, Jackson presents three pieces of evidence in support of his classification, none of which provide a compelling reason for excluding Nauruan from the Nuclear group.

Additional Evidence 1: Nauruan reflects /r/ in the word aar 'current' from POc *qaRus(a), while all Micronesian languages show loss of $* \mathrm{R}$ in this word. Jackson appears to cite the Nauruan word /æřæ-/ 'ocean current, rip tide' as a reflex of POc *qaRus (Blust \& Trussel). However, this Nauruan word is unlikely to be a reflex of this POc reconstruction. This word contains /řl, which continues PMc *c rather than *r. Kosraean acsr 'current' (Lee 1976) is possibly cognate, suggesting a reconstruction containing PMc $* \mathrm{c}$, though no such form is reconstructed by Bender et al. (2003).

Additional Evidence 2: PMc *f corresponds with Nauruan /p/ in the word for 'stone' but corresponds with $\varnothing$ in other Nauruan words, suggesting that reflexes of POc *patu 'stone' in Nauruan and the Nuclear Micronesian languages do not agree in grade. Jackson suggests that POc *b became Nauruan /p/ and POc *p was lost in Nauruan, but Jackson is only partially correct. POc *p was lost in Nauruan via PMc *f $>\varnothing$, but POc *b is not continued as Nauruan $/ \mathrm{p}^{\mathrm{j}} /$ or $/ \mathrm{p}^{\mathrm{V}} /$. Instead, the regular sound change is POc $* \mathrm{~b}>\mathrm{PMc} * \mathrm{p}>$ Nauruan $/ \mathrm{b}^{\mathrm{j}} /$ (or

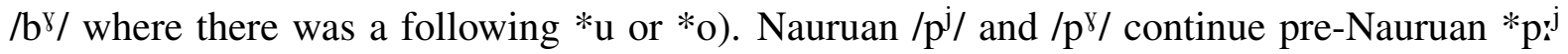
and ${ }^{*} \mathrm{p}^{\mathrm{X}}$ respectively, which result from reduplication and subsequent vowel syncope. Still, these observations do not explain the correspondence between PMc $* \mathrm{f}$ and Nauruan $/ \mathrm{p}^{\mathrm{j} /}$ if the etymology is in fact PMc *fatu $>$ Nauruan $/ \mathrm{p}^{\mathrm{j} e / ~ ' s t o n e, ~ h a r d ~ p a r t ~ o f ~ b o d y ' . ~}{ }^{13}$ If these are cognates, it would be the only known example where PMc $* \mathrm{f}$ became Nauruan $/ \mathrm{p} /$, though such exceptions have been claimed elsewhere in the Micronesian family. For example, Jackson (1983:329-330) claims that in Kosraean PMc *f became $p$ or $f$ in a few cases. If Nauruan $/ \mathrm{p}^{\mathrm{j} e /}$ is not an exceptional case, then there are two other possibilities for the origin of this word. First, it could be a loanword, but this seems unlikely because 'stone' is a Swadesh list item.

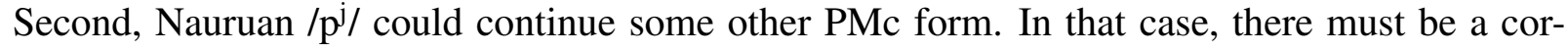
responding pre-Nauruan word which contains a geminate bilabial stop. There is some evidence for this possibility in the comparative data for Proto-Central Micronesian *pei 'stone structure', which is continued as Marshallese ppéy 'a platform of rocks'. If Nauruan continues a reduplication of *pei, then this form might also be reconstructed for PMc.

\footnotetext{
${ }^{12}$ Following Nathan (1973), Jackson incorrectly claims that POc *t is lost in Nauruan. Hughes (2020) shows that $\mathrm{PMc} * \mathrm{t}(<\mathrm{POc} * \mathrm{t})$ is continued as Nauruan $/ \mathrm{t} / \mathrm{or} / \mathrm{j} /$, the latter of which occurs where PMc $* \mathrm{t}$ was continued adjacent to pre-Nauruan $* \mathrm{i}$ or $* \mathrm{e}$. Pre-Nauruan $*_{\mathrm{j}}$ is subsequently lost in some word-edge environments.

${ }^{13}$ The expected continuation of PMc *fatu in Nauruan is /ej/.
} 


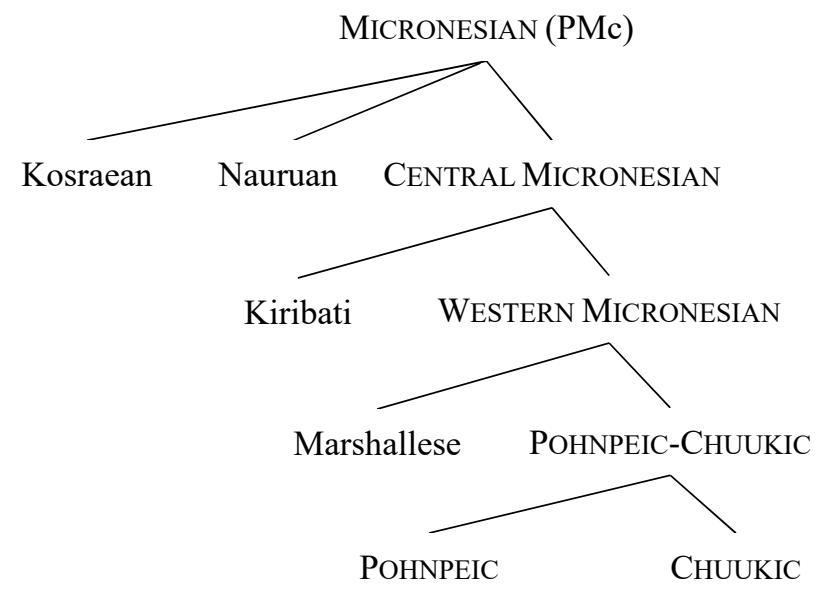

Figure 2: The Micronesian Language Family, Hypothesis 1

Additional Evidence 3: Nauruan fails to reflect the replacement of POc *R by a velar nasal in PMc *maini (-mow < POc *mauRi) 'left side' and the replacement of final *i in PMc *wakara 'root' (awori- < POc *wakaR(i)). Jackson claims that Nauruan does not continue PMc ${ }^{*} \mathrm{y}$ in the word for 'left side'. The equivalent reconstruction in Bender et al. (2003) is Proto-Central Micronesian *ma\{i,u\} ji 'left handed', which Hughes (2020) suggests should be reconstructed for PMc. The Nauruan reflex identified by Hughes (2020), /e-da-m ${ }^{8}$ ow/ 'left hand side', is missing the phoneme $/ \mathrm{y} /$, but this appears to be due to internal sound change

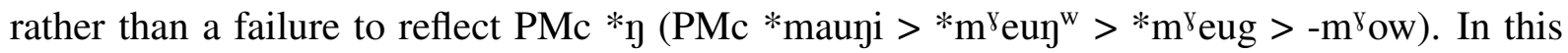
case a series of sound changes makes Nauruan's continuation of PMc * $y$ opaque $\left(* \eta>{ }^{*} \eta^{\mathrm{w}}>\right.$ $* \mathrm{~g}>\mathrm{w}$ ). Jackson also claims that Nauruan continues POc *wakar-i rather than PMc *wakara 'root', because Nauruan reflects thematic /i/ upon suffixation. However, Nauruan appears to employ epenthetic schwa in this word, [ə], rather than /i/ (cf. Nathan 1973:492). In light of this, it seems unnecessary to claim continuation of POc *wakar-i rather than PMc *wakara.

3. Classifying Nauruan within the Micronesian family. Having established that there is no clear evidence for excluding Nauruan from the Nuclear Micronesian group, Nauruan's precise classification within the Micronesian family must be considered. Of particular importance is whether or not Nauruan reflects the merger of $\mathrm{PMc} * \mathrm{~s}$ and $* \mathrm{~S}$, a sound change that defines the Central Micronesian group. Under the current model of the Micronesian family, Central Micronesian includes all Micronesian languages other than Kosraean (Figure 1; see also Bender et al. 2003:3). If Nauruan also does not reflect the merger of PMc *s and $* S$, then it should be excluded from the Central Micronesian group along with Kosraean. This possibility is illustrated in Figure 2.

There is evidence to suggest that Nauruan does not reflect the merger of PMc *s and $* \mathrm{~S}$, which would support the hypothesis illustrated in Figure 2. In all the relevant comparisons identified so far, PMc $*_{\mathrm{S}}$ is continued as Nauruan /d/. PMc *S is also continued as Nauruan /d/, except where it was adjacent to pre-Nauruan $*^{*}$, in which case it is continued as Nauruan /g/. Consider, for example, the Nauruan word /roga/ 'rise, ascend' which continues PMc *ro-Sa, ${ }^{14}$ or the Nauruan word $/ \mathrm{m}^{\mathrm{j}} \mathrm{ago} /$ 'deep sea' which continues PMc *ma-Sawa 'deep sea,

\footnotetext{
${ }^{14}$ This reconstruction is suggested by Hughes (2020), combining the PMc suffix *-Sa 'up' (cf. *Sake in Bender
} 


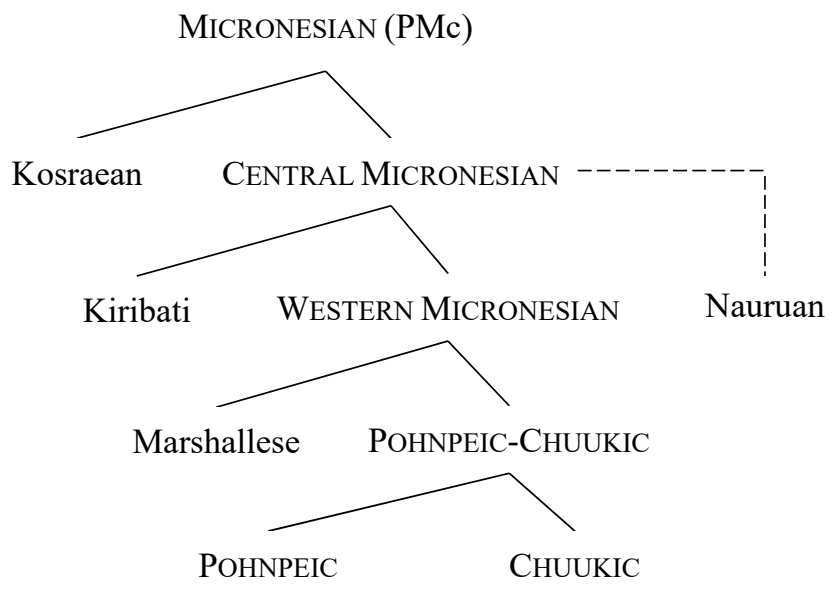

Figure 3: The Micronesian Language Family, Hypothesis 2

open sea' (noting the Nauruan internal sound change *aw $>*^{*}$ ew $>*_{0}$ and final vowel loss). Additional examples of correspondences between PMc $* \mathrm{~S}$ and Nauruan /g/ can be found in the appendix in Hughes (2020), each of which suggest that $* S$ was continued adjacent to preNauruan $*$ o.

At present, it is still possible that Nauruan did participate in the merger of PMc $*_{\mathrm{s}}$ and $* \mathrm{~S}$. Showing this would require evidence that PMc *s (like ${ }^{*} \mathrm{~S}$ ) is continued as Nauruan /g/ where it was adjacent to pre-Nauruan $*^{\mathrm{o}}$. In that case, PMc $*_{\mathrm{s}}$ and $*_{\mathrm{S}}$ would have merged as pre-Nauruan $*$ d, which was later continued as $/ \mathrm{g} /$ where it was adjacent to $*_{0}$. So far, no comparisons have been identified which show a clear case of pre-Nauruan $*_{\mathrm{o}}$ adjacent to $*_{\mathrm{d}}(<$ PMc *s). If any such words are discovered this will be very helpful in determining if PMc *s and $* S$ merged in Nauruan, and likewise, whether or not Nauruan should be classified outside of or within Central Micronesian. If the merger did not occur, then PMc *s will be continued as Nauruan /d/ even where it was continued adjacent to pre-Nauruan $*_{0}$. In that case, Nauruan should be classified outside of the Central Micronesian Group (Figure 2). If the merger did occur, then PMc *s will be continued as Nauruan /g/ where it was continued adjacent to pre-Nauruan $*_{0}$, in which case Nauruan should be classified somewhere within the Central Micronesian group. The latter possibility is illustrated in Figure 3.

If Nauruan is shown to belong within Central Micronesian, then the question of where it should be placed within this group will still remain. There are two Micronesian etyma that could help determine this, but unfortunately, neither of these have identified Nauruan cognates at this time. The relevant reconstructions are PMc *kiaZo 'outrigger boom' and PMc *laZe 'kind of coral' (Bender et al. 2003). These are the only two PMc reconstructions that contain $* \mathrm{Z}$, which is continued as Kiribati $r$ and which is lost in all Western Micronesian languages. If Nauruan reflects the loss of PMc *Z, this could support classifying Nauruan within Western Micronesian as a sister to Marshallese and the Pohnpeic-Chuukic group. Alternately, if Nauruan continues $\mathrm{PMc} * \mathrm{Z}$ as some (probably coronal) consonant this could support classifying Nauruan alongside Kiribati, within Central Micronesian but outside of the Western Micronesian group. Identifying Nauruan cognates for these two words, if there are any, is a priority in et al. (2003), which lists apparent reflexes of $\left.*_{-} \mathrm{Sa}\right)$ and PMc *(o)ro $\left(<\mathrm{POc} *_{\mathrm{oRo}}\right)$. 
future work with Nauruan speakers.

There are also some potential shared innovations between Nauruan and Central Micronesian languages that can be observed. Consider that among the Micronesian languages only Nauruan and Kiribati continue PMc ${ }^{*} \mathrm{p}$ as a voiced stop $b$ (Nauruan $\left./ \mathrm{bj} /\right)$. Additionally, both Nauruan and Kiribati continue PMc $* 1$ as $n$. For now, it remains unclear if these can be considered shared innovations between Nauruan and Kiribati. There are also correspondences between PMc *1 and $n$ in several Chuukic languages, including Chuukese, Woleaian and Satawalese, the latter of which has variation between $l$ and $n$ synchronically. Also of note is that PMc ${ }^{*} \mathrm{k}$ appears to have undergone a weakening processes in Nauruan, having been lost word-initially before $* \mathrm{a}$ and continued as $/ \mathrm{g} /$ elsewhere, or as $/ \mathrm{k} /$ where there was a pre-Nauruan geminate $\left({ }^{*} \mathrm{~g}:>\mathrm{k}\right)$. In comparison, Woleaian, Saipan Carolinian and Saipan Carolinian (Tanapag) also continue PMc ${ }^{*} \mathrm{k}$ as $/ \mathrm{g} /$, each of which are Chuukic languages, and in other members of the Chuukic group * $\mathrm{k}$ is lost. This suggests a general weakening of $\mathrm{PMc} * \mathrm{k}$ in these languages. At this time, it remains unclear if any of these ${ }^{*} \mathrm{k}$ lenition processes can be considered shared innovations with Nauruan.

\section{References}

Bender, Byron. 1971. Micronesian languages. In Thomas A. Sebeok, Donald Bowen, Isidore Dyen, George W. Grace, Stephen A. Wurm, Geoffrey N. O’Grady, Alexandra Ramsay \& Lucia Hadd Zoercher (eds.), Linguistics in Oceania (Current Trends in Linguistics 8). 426465. The Hague: Mouton.

Bender, Byron, Jeffrey Marck, Kenneth Rehg, Ho-min Sohn, Ward Goodenough, Frederick Jackson, Stephen Trussel \& Judith Wang. 2003. Proto-Micronesian Reconstructions - I. Oceanic Linguistics 42(1). 1-110. https://doi.org/10.1353/ol.2003.0002.

Blust, Robert \& Stephen Trussel. 2010 (updated 2020). The Austronesian Comparative Dictionary. http://www.trussel2.com/ACD/.

Davidson, Jeremy H. C. S. (ed.). 1990. Pacific island languages: Essays in honour of G.B. Milner. London: School of Oriental and African Studies, University of London.

Dyen, Isidore. 1965. A lexicostatistical classification of the Austronesian languages (Indiana University Publications in Anthropology and Linguistics, Memoir 19). Bloomington: Indiana University.

Hughes, Kevin. 2020. The synchronic and diachronic phonology of Nauruan: Towards a definitive classification of an understudied Micronesian language: New York: City University of New York dissertation.

Jackson, Frederick H. 1983. The internal and external relationships of the Trukic languages of Micronesia. Manoa: University of Hawaii dissertation.

Jackson, Frederick H. 1984. On lexical diffusion as subgrouping evidence. Paper presented at the Annual Meeting of the Linguistic Society of America. Baltimore, MD.

Jackson, Frederick H. 1986. On determining the external relationships of the Micronesian languages. In Paul A. Geraghty, Lois Carrington \& S. A. Wurm (eds.). FOCAL II: Papers from the fourth International Conference on Austronesian Linguistics. 201-238. Canberra: Dept. of Linguistics, Research School of Pacific Studies, Australian National University.

Lee, Kee-dong. 1976. Kusaiean-English dictionary. Honolulu: University of Hawaii Press.

Lynch, John, Malcolm Ross \& Terry Crowley. 2011. The Oceanic languages. New York: Routledge.

Marck, Jeffrey C. 1975. The origin and dispersal of the Proto Nuclear Micronesians. Iowa City: University of Iowa dissertation. 
Nathan, Geoffrey S. 1973. Nauruan in the Austronesian Language Family. Oceanic Linguistics 12(1/2). 479-501.

Ross, Malcolm D. 1988. Proto Oceanic and the Austronesian languages of western Melanesia. Canberra: Australian National University. 